\title{
Exotic macroalga Gracilaria vermiculophylla provides superior nursery habitat for native blue crab in Chesapeake Bay
}

\author{
Cora Ann Johnston ${ }^{1,3}$, Romuald N. Lipcius ${ }^{2, *}$ \\ ${ }^{1}$ School of Natural Science, Hampshire College, Amherst, Massachusetts 01002, USA \\ ${ }^{2}$ Virginia Institute of Marine Science, College of William \& Mary, PO Box 1346, Gloucester Point, Virginia 23062, USA
}

${ }^{3}$ Present address: Department of Entomology, University of Maryland, College Park, Maryland 20742, USA

\begin{abstract}
Exotic species often reduce the abundance or diversity of species in marine ecosystems, but some exotics may benefit native species, such as when habitat is enhanced. In Chesapeake Bay, the exotic macroalga Gracilaria vermiculophylla (Rhodophyta) has flourished and dispersed widely, yet the consequences for native species diversity and abundance are not well known. We experimentally examined the capacity of the structurally complex G. vermiculophylla to provide nursery habitat for the blue crab Callinectes sapidus in Chesapeake Bay, where native eelgrass nursery habitat has dwindled. We also examined ontogenetic shifts in survival across alternative nursery habitats. In field surveys, juvenile density was similar in macroalgae and eelgrass, but lower in unvegetated mud habitat. In field experiments, juvenile survival was positively related to crab size in mud but negatively in eelgrass, confirming the paradigm of a predationinduced ontogenetic shift from seagrass to unvegetated habitat. In contrast, irrespective of crab size, survival was higher in macroalgae than in either native habitat. Thus, exotic habitat-forming macroalgae can compensate for severe declines in seagrass nurseries, and facilitate the emergence of a novel ecosystem.
\end{abstract}

KEY WORDS: Exotic species $\cdot$ Ontogenetic habitat shift $\cdot$ Predation $\cdot$ Prey size refuge $\cdot$ Novel ecosystem $\cdot$ Emerging ecosystem $\cdot$ Macroalgae $\cdot$ Seagrass

\section{INTRODUCTION}

\section{Exotic species and novel ecosystems}

Exotic species have predominantly severe, negative effects on the diversity and abundance of native species (Mooney \& Cleland 2001, Goodenough 2010). Recently, however, potentially beneficial effects of exotic species have been identified (e.g. Rodriguez 2006, Martin \& Valentine 2011, Schlaepfer et al. 2011). For example, although exotic species may outcompete native species, in degraded ecosystems they may fill ecological roles left vacant by declining native species (Rodriguez 2006). Various species of macroalgae are often viewed as perilous invaders, because they thrive under eutrophic conditions and may outcompete or exclude seagrasses, yet they can also be integral to estuarine nutrient cycling and ecosystem function (Penhale \& Thayer 1980, Sand-Jensen \& Borum 1991, Duarte 1995, Schlaepfer et al. 2011).

Gracilaria vermiculophylla is a macroalga native to eastern Asia (Ohmi 1956, Bellorin et al. 2004) that has colonized the coasts of North America and Europe (Bellorin et al. 2004, Thomsen et al. 2006a,b, 2007, Freshwater et al. 2006). Its spores attach to natural or 
anthropogenic substrates in estuaries and bays, and it may form extensive beds in the intertidal and shallow sublittoral zones (Bellorin et al. 2004, Freshwater et al. 2006). Although high macroalgal biomass $>100 \mathrm{~g} \mathrm{~m}^{-2}$ can lead to anoxia beneath dense mats and subsequent reductions in diversity and faunal biomass (Thomsen et al. 2006b), intermediate levels of $G$. vermiculophylla biomass may benefit shelterdependent species by adding complexity to unvegetated habitats such as mud and sand flats (Thomsen et al. 2010, Byers et al. 2012).

Throughout the world, there has been increasing recognition of novel (=emerging) ecosystems, which are characterized by altered species assemblages, often due to anthropogenic impacts such as species introductions (Hobbs et al. 2006, 2009). Moreover, widespread human influence on natural systems can cause such severe degradation that restoration of historical ecosystem function is impractical (Jackson \& Hobbs 2009, Schlaepfer et al. 2011). However, where vacant niches of native species are filled by exotic species, some ecosystems can re-emerge and function effectively, perhaps benefiting imperiled native species (Hobbs et al. 2009, Schlaepfer et al. 2011).

Here we experimentally examined whether the exotic habitat-forming macroalga Gracilaria vermiculophylla provides effective nursery habitat for the imperiled native blue crab Callinectes sapidus (Lipcius \& Stockhausen 2002) in a marine ecosystem compromised by severe declines of seagrass (Orth \& Moore 1984). Consequently, G. vermiculophylla may serve as a beneficial species in an emerging novel ecosystem. Furthermore, because it has been proposed that blue crab juveniles exhibit an ontogenetic habitat shift between alternative nursery habitats (Lipcius et al. 2007), we also examined the effect of juvenile crab size upon survival in the exotic macroalga and in 2 native nursery habitats.

\section{Ontogenetic tradeoffs in nursery habitats}

As individuals grow, fitness may be maximized by dispersing between habitats that offer different sizedependent costs and benefits (i.e. tradeoffs in growth rate and predation risk; Werner \& Gilliam 1984). Thus, experimentally analyzing mortality $(\mu)$ risk and growth rate $(g)$ allows identification of shifts in habitat choice, the factor(s) determining those choices, and the suitability of each habitat as a nursery (Beck et al. 2001). Such species may display patterns that minimize mortality, maximize growth or minimize $\mu / g$, depending on which factors are most important in determining habitat preference (Werner \& Gilliam 1984).

Such analyses have been conducted for various mobile aquatic species through the use of field survival and growth studies. In bluegill sunfish Lepomis macrochirus populations, discrete size-dependent dispersal events between littoral and pelagic habitats depended upon both predation risk and growth rate; predation pressure was, however, the primary determinant of habitat choice (Werner \& Hall 1988). Similarly, habitat preference of mummichog Fundulus heteroclitus was positively associated with the availability of refuges from predation, regardless of growth potential within a habitat (Halpin 2000). The smallest size class of juvenile Nassau grouper Epinephelus striatus preferred habitats that minimized predation risk, and the largest juveniles only underwent growth-dependent dispersal once predation was minimized (Dahlgren \& Eggleston 2000). In damselflies (Enallagma and Ischnura spp.), growth rates of the 2 genera varied in different habitats, but these alterations were primarily driven by dragonfly and fish predation (McPeek et al. 2001). These studies collectively demonstrated that relative habitat suitability and size-specific habitat shifts could be identified through experimental analysis of mortality and growth in the field, and that predation pressure played a predominant role in determining tradeoffs associated with habitat choice.

Given that Gracilaria vermiculophylla may serve as nursery habitat, where tradeoffs in predation risk and growth rate can drive ontogenetic habitat shifts (Craig \& Crowder 2000), we also experimentally compared survival as a function of size in 2 native nursery habitats (eelgrass Zostera marina and unvegetated mud flats) and in G. vermiculophylla, to assess whether blue crabs encounter similar ontogenetic tradeoffs in native and exotic juvenile habitats.

\section{Blue crab use of nursery habitat}

Small and large juveniles of Callinectes sapidus differentially inhabit vegetated primary nurseries and unvegetated secondary nurseries, respectively (Pardieck et al. 1999, Lipcius et al. 2007). This has been proposed to be due to a size-specific habitat shift during ontogeny, given that crabs $<30 \mathrm{~mm}$ carapace width (CW) are abundant within seagrass beds, whereas larger juveniles inhabit sublittoral mudflats, where they may escape density-dependent growth reduction, cannibalism and predation (Pile et al. 1996, Hovel \& Lipcius 2001, Lipcius et al. 2007). 
Small, pre-dispersal juveniles benefit from the structural refuge provided by seagrass. However, Chesapeake Bay has experienced severe declines in Zostera marina, including mass defoliations (Orth \& Moore 1984, Orth et al. 2010), which may partly explain the inability of the blue crab population to recover from an $80 \%$ decline in biomass since the early 1990s (Lipcius \& Stockhausen 2002). Thus, if Gracilaria vermiculophylla is effective as alternative nursery habitat, as Thomsen and colleagues have posited for invertebrates including the blue crab (Thomsen et al. 2009, Thomsen 2010), then it may compensate for the detrimental effects of eelgrass loss on blue crab population recovery.

\section{Experimental rationale and objectives}

Due to the dominant influence of predation pressure on habitat choice and based on earlier findings that blue crab food availability is similar between primary and secondary nursery habitats (Seitz et al. 2005), we exclusively assessed survival of juvenile blue crabs in Gracilaria vermiculophylla, Zostera marina and mud. We hypothesized that as eelgrass becomes scarce in Chesapeake Bay, juvenile crabs will readily use $G$. vermiculophylla as an alternative nursery habitat. We further hypothesized that the growth of structurally complex G. vermiculophylla on characteristically unvegetated mud habitat would alter the dynamics of blue crab ontogenetic habitat use. Essentially, as macroalgae (potential primary nursery) grows on extensive mud flats (secondary nursery), the increase in vegetated habitat availability will likely broaden the size range of juveniles in macroalgal habitats by supplying refuge for both primary and secondary nursery-phase individuals, thereby diminishing any size-specific habitat shift during development (Lipcius et al. 2007).

The variables that we examined included (1) crab size, which affects vulnerability to predation (Hines \& Ruiz 1995), (2) habitat type, which alters juvenile survival and habitat choice (Lipcius et al. 2007), and (3) trial duration, which may affect crab survival due to variation in the predator assemblage by time of day and tidal fluctuations. Modeling these 3 factors individually and in combination, multiple alternative patterns of survival could be expected. Larger crabs were anticipated to live longer than small crabs since larger crabs have a more limited predator assemblage and are less susceptible to cannibalism $\left(\mathrm{H}_{1}\right.$ : crab size) (Hines \& Ruiz 1995, Lipcius et al. 2007). Due to the refuge provided by heterogeneous struc- ture, we expected juvenile survival to be higher in both vegetated habitats when no effect of size was considered $\left(\mathrm{H}_{2}\right.$ : habitat). Taking into account habitat and size effects separately, we expected large juveniles in vegetated habitats to survive best $\left(\mathrm{H}_{3}\right.$ : habitat, size). However, by adding the interaction between size and habitat, based on previous findings that small juveniles inhabit seagrass whereas larger juveniles predominate in mud flats, we predicted a complementary pattern in which small juveniles survive best in structured habitats whereas larger individuals survive best in unvegetated habitat $\left(\mathrm{H}_{4}\right.$ : size $\times$ habitat) (Pile et al. 1996, Lipcius et al. 2007). Within each habitat, juvenile survival was expected to decline with time until only crabs with a size-based refuge from predation survived almost indefinitely ( $\mathrm{H}_{5}$ : duration, size, habitat) (Heck \& Spitzer 2001). Using experimental studies and field sampling, we analyzed the survival and distribution of early juvenile (5 to $45 \mathrm{~mm} \mathrm{CW}$ ) blue crabs in Zostera marina, Gracilaria vermiculophylla and mud to detect sizedependent habitat shifts and determine the relative suitability of each habitat.

\section{MATERIALS AND METHODS}

\section{Study sites}

Studies were conducted in vegetated and unvegetated habitats in the York River, a tributary of lower Chesapeake Bay, during July 2007. Sandy Point (37 $\left.15^{\prime} 52.00^{\prime \prime} \mathrm{N}, 76^{\circ} 23^{\prime} 49.46^{\prime \prime} \mathrm{W}\right)$ and the mouth of Perrin's Creek (37 $\left.15^{\prime} 43.78^{\prime \prime} \mathrm{N}, 7^{\circ} 25^{\prime} 22.14^{\prime \prime} \mathrm{W}\right)$ each contained one Zostera marina site. Habitats of Gracilaria vermiculophylla and mud were both investigated near the mouth of Perrin's Creek and in a cove adjacent to Carmine's Island (37¹7' $04.55^{\prime \prime} \mathrm{N}$, $\left.76^{\circ} 31^{\prime} 59.95^{\prime \prime} \mathrm{W}\right)$. Patterns of survival were consistent across habitat type, regardless of site; thus we considered samples spatially independent. All sites were consistently submerged but $<2 \mathrm{~m}$ deep with a tidal range of $0.7 \mathrm{~m}$. The studied reach of the York River is $\sim 11 \mathrm{~km}$ from the mouth, where it joins Chesapeake Bay. The reach is consistently polyhaline; in summer 2007, salinity ranged from 18 to 23 psu, dissolved oxygen ranged from 3 to $10 \mathrm{mg} \mathrm{l}^{-1}$, turbidity ranged from 10 to $30 \mathrm{NTU}$, and temperature increased from 20 to $30^{\circ} \mathrm{C}$ from June until September (Virginia Estuarine \& Coastal Observing System data from summer 2007, Gloucester Point Continuous Monitoring Station). Both seagrass beds consisted primarily of $Z$. marina at $70-100 \%$ cover but with small propor- 
tions of widgeon grass Ruppia maritima scattered throughout (Orth et al. 2008). Although macroalgal abundance was not assessed at the time of this study, beds of $G$. vermiculophylla were consistently present at our sites (C.A.J. pers. obs.).

\section{Crab density and size distribution}

To determine natural juvenile density and distribution in the 3 habitats, crabs were sampled using trawls and standard ring suction methods, and corrected for 21 and $78 \%$ efficiencies, respectively (Orth \& van Montfrans 1987). Trawling was conducted with a $4.9 \mathrm{~m}$ otter trawl of $2.5 \mathrm{~cm}$ mesh lined with $0.6 \mathrm{~cm}$ mesh. Rings covered $1.68 \mathrm{~m}^{2}$ and were suctioned for 6 min each. We conducted 14, 25 and 16 sampling operations in Gracilaria vermiculophylla, mud and eelgrass, respectively. Captured crabs were counted and measured, and the volume of G. vermiculophylla in the samples was measured by volumetric displacement. Only juvenile crabs ( $\leq 100 \mathrm{~mm} \mathrm{CW}$ ) were included in this analysis.

\section{Survival}

Juvenile crabs were collected by trawling and seining along coves and creeks adjacent to our study sites in the York River. Crabs were held in flow-through seawater tanks for no longer than $24 \mathrm{~h}$ before experimental deployment. Each crab was measured to the nearest $0.1 \mathrm{~mm}$ spine-to-spine $\mathrm{CW}$ with calipers and then tethered by adhering $30 \mathrm{~cm}$ of monofilament fishing line to the carapace with cyanoacrylate superglue. Tethering estimates the relative differences in survival between experimental treatments, and does not produce treatment-specific bias (Peterson \& Black 1994) when comparing vegetated and unvegetated habitats (Pile et al. 1996, Hovel \& Lipcius 2001, Lipcius et al. 2005).

Small crabs (5 to $25 \mathrm{~mm} \mathrm{CW}$ ) were tethered to $3.6 \mathrm{~kg}$ test line with a single drop of glue. For larger crabs (26 to $45 \mathrm{~mm} \mathrm{CW}$ ), a noose of $9.1 \mathrm{~kg}$ test line was glued around their carapace spines. Visual observations during tethering and deployment verified that tethered crabs had sufficient freedom of movement (e.g. the ability to swim, walk and burrow).

To ensure that molting and escape from tethers did not cause overestimates of predation, we conducted tether retention studies on 24 crabs in the laboratory. Tethered crabs were secured in flow-through seawater tanks and checked for tether retention over $36 \mathrm{~h}$.
Retention rates were high across all sizes (small = $9 / 10$, large $=14 / 14$ ). Since tethered crabs were never deployed in the field for longer than $25 \mathrm{~h}$ during survival studies, estimates of survival were considered accurate.

In the field, the end of each crab tether was connected to a staple that was secured with $9.1 \mathrm{~kg}$ test line to a PVC marker pole $1 \mathrm{~m}$ away. Crabs were sufficiently distant from the marker poles to prevent biases due to the pole structure, either as a crab refuge or predator attractant. Tethered crabs were deployed in Gracilaria vermiculophylla $(\mathrm{n}=51)$, Zostera marina $(\mathrm{n}=35)$ and mud $(\mathrm{n}=54)$. In G. vermiculophylla treatments, a large handful $(<1$ l) of $G$. vermiculophylla was secured beneath the staple to ensure that the vegetation was consistently available to the tethered crab. To maintain independence, tethers were located $>3 \mathrm{~m}$ apart, which placed crabs at or below natural densities, potentially preventing unnaturally high predation rates due to induced search by motile predators.

Tethered crabs were checked for survival within 12 to $25 \mathrm{~h}$ of deployment. This time interval ensured that each crab was tethered through a full tide cycle and either dawn or dusk, which should smooth differences in predation pressure based on water depth and time of day. The actual time interval was used as a covariate in statistical analyses, but did not affect survival significantly (see 'Results'). Predation was determined by the presence of carapace pieces on the line, a chewed line or a cut line (Lipcius et al. 2005).

\section{Statistical analysis}

Based on each of our 5 hypotheses, we developed models $g_{1}-g_{5}$ following an information-theoretic approach (Burnham \& Anderson 2002, Anderson 2007). Within these models, crab size $(\mathrm{mm})$ and trial duration (h) were continuous variables, whereas habitat type was a categorical factor with 3 levels (mud, Zostera marina and Gracilaria vermiculophylla).

Model-specific crab survival, recorded as 1 (alive) or 0 (dead), was analyzed for probability of survival under the various experimental treatments and conditions (i.e. habitat, crab size, time since deployment) using logistic regression. The resulting log-likelihood values from each model were used to calculate Akaike's information criterion (AIC) values (Burnham \& Anderson 2002, Anderson 2007), specifically $\mathrm{AIC}_{\mathrm{C}}$ a second-order bias correction estimator. The 
$\Delta_{i}$ values were used to rank the different models $\left(g_{i}\right)$ against the model with the lowest $\mathrm{AIC}_{\mathrm{c}}$. Model probabilities $\left(w_{i}\right)$ for each model estimated the probability that a particular model $g_{i}$ was the best model; these were used to rank models. Any model with $w_{i}$ less than 0.05 was eliminated. To further distinguish between competing models, individual parameter estimates were examined.

Subsequently, parameter estimates of models warranting further consideration were used to calculate binomial survival probabilities as:

$$
\theta=\frac{e^{\left(\alpha+\beta_{1} x_{1}+\beta_{2} x_{2}+\ldots+\beta_{i} x_{i}\right)}}{1+e^{\left(\alpha+\beta_{1} x_{1}+\beta_{2} x_{2}+\ldots+\beta_{i} x_{i}\right)}}
$$

where $\theta$ is the probability of survival, $\alpha$ is a parameter (constant) for the baseline condition and $\beta_{i}$ comprises parameters representing increases or decreases in survival due to the effects of corresponding independent variables $x_{i}$. Crab size $\left(x_{1}\right)$ and trial duration $\left(x_{4}\right)$ were represented by single variables since they are continuous. Each habitat type within the categorical habitat factor was represented by a dummy variable $\left(x_{2}, x_{3}\right)$. Mud was designated the constant $(\alpha)$ due to its relative lack of structure. For mud, $x_{2}=x_{3}=0$; for Zostera marina, $x_{2}=1$ and $x_{3}=0$; and for Gracilaria vermiculophylla, $x_{2}=0$ and $x_{3}=1$.

Natural density and size distribution were also compared across the different habitats from the field collections, and the relationship between crab density and Gracilaria vermiculophylla volume was analyzed using non-linear least-squares regression.

\section{RESULTS}

\section{Natural density and size distribution}

Blue crab density (Table 1) was high and approximately equal in Zostera marina (5.7 crabs $\mathrm{m}^{-2}$ ) and Gracilaria vermiculophylla (5.6 crabs $\mathrm{m}^{-2}$ ), and nearly 30-fold higher than that in unvegetated mud habitat $\left(0.2\right.$ crabs $\left.\mathrm{m}^{-2}\right)$. Mean densities in seagrass and $G$. vermiculophylla did not differ significantly from each other, but both were significantly higher than density in mud (ANOVA, p $<0.05$; StudentNewman-Keuls post hoc tests, $\mathrm{p}=0.05$ ).

Both Zostera marina and Gracilaria vermiculophylla harbored mostly young juveniles $<30 \mathrm{~mm}$ CW (Fig. 1), the size at which juveniles disperse to unvegetated mud and sand habitats (Lipcius et al. 2007). There was a positive correlation between crab density and G. vermiculophylla volume $\left(\mathrm{r}^{2}=\right.$ $0.44, \mathrm{p}<0.1)$, but the sample size was relatively low $(\mathrm{n}=11)$, such that the relationship requires further verification in the field. However, the positive relationship has been repeated elsewhere (Thomsen 2010, Thomsen et al. 2010), suggesting that there is a significant positive relationship between blue crab density and G. vermiculophylla volume.

Table 1. Callinectes sapidus. Natural densities of juvenile blue crab by habitat in samples taken in July 2007 at York River, Chesapeake Bay. Mean crab densities in eelgrass (Zostera marina) and Gracilaria vermiculophylla did not differ significantly from each other, but both were significantly higher than density in mud (ANOVA, $p<0.05$; Student-Newman-Keuls post hoc tests, $\mathrm{p}=0.05$ )

\begin{tabular}{|lccc|}
\hline Habitat & $\mathrm{n}$ & $\begin{array}{c}\text { Mean density } \pm \text { SEM } \\
\text { (ind. per } \mathrm{m}^{2} \text { ) }\end{array}$ & 95\% CI \\
\hline Eelgrass & 16 & $5.74 \pm 0.97$ & $3.66,7.79$ \\
Gracilaria & 14 & $5.61 \pm 1.25$ & $2.90,8.31$ \\
Mud & 25 & $0.17 \pm 0.07$ & $0.02,0.32$ \\
\hline
\end{tabular}

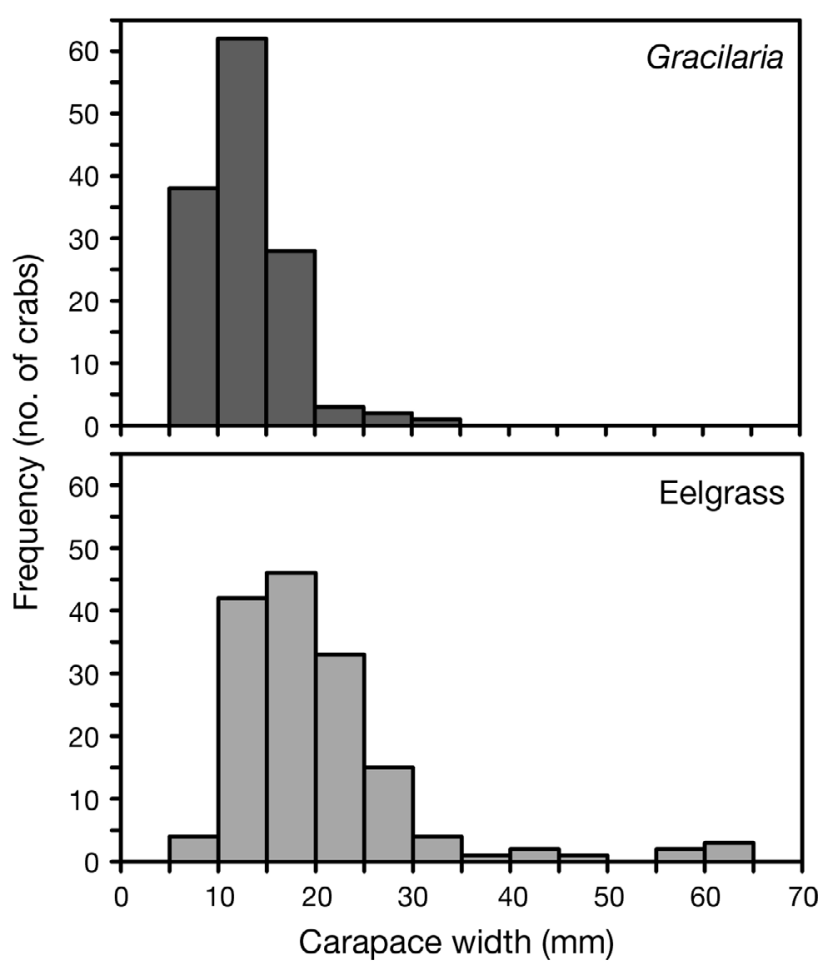

Fig. 1. Callinectes sapidus. Size (carapace width) distribution of juvenile blue crab by habitat (Gracilaria vermiculophylla and eelgrass) from data gathered in July 2007 at York River, Chesapeake Bay. Mud was not included because the total number of blue crabs caught was too low to portray a histogram 


\section{Survival}

Model $g_{1}$ (size only) was eliminated from further consideration because its probability was less than 0.05 (Table 2) and its effect size was negligible (Table 3). For the remaining models $\left(g_{2}-g_{5}\right), \Delta_{i}$ values were $<5$ and $w_{i}$ probabilities were $>0.05$, such that they could not be excluded from consideration (Anderson 2007). Thus, we examined the significance of the model parameter estimates. Model $g_{3}$ was not considered further because its addition of a single variable (size) to $g_{2}$ increased the $\mathrm{AIC}_{\mathrm{c}}$ value by approximately 2 , which is indicative of an insignificant 'pretend' variable (Anderson 2007), and it did not have a major effect on the response variable (Table 3). Similarly, model $g_{4}$ was eliminated because it also increased the $\mathrm{AIC}_{\mathrm{c}}$ value by approximately 2 after the addition of one variable (trial duration), and because the parameter estimate for trial duration had a statistically non-significant ( $p \gg 0.05$ ) and inconsequential effect size (Table 3).

Table 2. Akaike's information criterion (AIC) calculations for the logistic regression models corresponding to the different hypotheses represented by the models $g_{i} . k$ is the number of parameters, including variance $\left(\sigma^{2}\right)$, in model $i_{i} \boldsymbol{L}\left(g_{i} / X=x\right)$ is the log-likelihood; $\mathrm{AIC}_{\mathrm{c}}$ is the corrected AIC value; $\Delta_{i}$ is the difference between model $i$ and the best model in the set; and $w_{i}$ is model probability of fitting the observed data

\begin{tabular}{|lccccc|}
\hline Model & $k$ & $\boldsymbol{L}\left(g_{i} / X=x\right)$ & $\mathrm{AIC}_{\mathrm{c}}$ & $\Delta_{i}$ & $W_{i}$ \\
\hline$g_{1}$ & 3 & -86.241 & 178.658 & 11.116 & 0.01 \\
$g_{2}$ & 4 & -79.623 & 167.542 & 0 & 0.62 \\
$g_{3}$ & 5 & -79.560 & 169.568 & 2.026 & 0.23 \\
$g_{4}$ & 6 & -79.550 & 171.732 & 4.190 & 0.08 \\
$g_{5}$ & 7 & -78.503 & 171.854 & 4.312 & 0.07 \\
\hline
\end{tabular}

Of the 2 remaining models $\left(g_{2}\right.$ and $\left.g_{5}\right)$, we chose $g_{5}$ as the optimal model because it included the variables in model $g_{2}$ and because the interaction effect sizes were statistically significant $(p<0.05)$ and substantial (Table 3), indicating that the relationship between the probability of survival and crab size differed significantly by habitat type (sigmoid non-linear regression, $r^{2}=0.40, p=0.041 ;$ Fig. 2). For the unvegetated (mud) habitat, survival probability was positively related to crab size, whereas for Zostera marina, survival was inversely related to crab size (Fig. 2), as predicted by the hypothesis of an ontogenetic shift in habitat from seagrass to mud as juveniles grow. In contrast, survival was generally higher and independent of

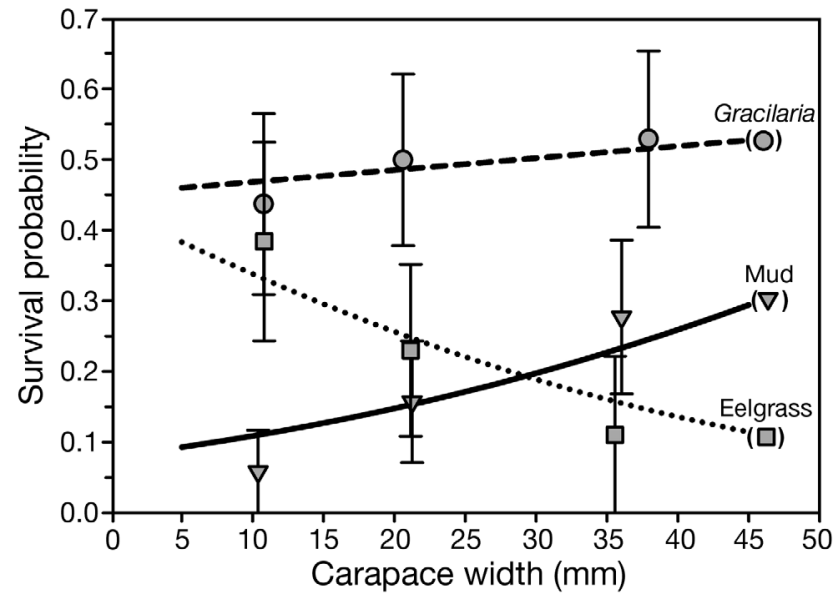

Fig. 2. Callinectes sapidus. Juvenile blue crab probability of survival by size (carapace width) within each habitat (Gracilaria vermiculophylla, mud and eelgrass) from survival probability models and field survival experiments during summer 2007 in the York River, Chesapeake Bay. The functions are derived from model $g_{5}$ (habitat type $\times$ crab size). The survival probability points are from the field experimental data. Means $\pm 1 \mathrm{SE}$

Table 3. Parameter estimates with $95 \%$ confidence intervals (in parentheses) from logistic regression models $\left(g_{1}-g_{5}\right)$

\begin{tabular}{|c|c|c|c|c|c|c|c|}
\hline \multirow{2}{*}{ Model $k$} & \multirow{2}{*}{ Intercept } & \multicolumn{6}{|c|}{ - Variables } \\
\hline & & $\begin{array}{c}X_{1} \\
\text { size }\end{array}$ & $\begin{array}{c}x_{2} \\
\text { eelgrass }\end{array}$ & $\begin{array}{c}x_{3} \\
\text { macroalgae }\end{array}$ & $\begin{array}{c}x_{4} \\
\text { trial } \\
\text { duration }\end{array}$ & $\begin{array}{c}x_{5} \\
\text { eelgrass } \\
\times \text { size }\end{array}$ & $\begin{array}{c}x_{6} \\
\text { macroalgae } \\
\times \text { size }\end{array}$ \\
\hline$g_{1}$ & $\begin{array}{c}-0.99 \\
(-1.40,-0.57)\end{array}$ & $\begin{array}{c}0.01 \\
(-0.01,0.02)\end{array}$ & & & & & \\
\hline$g_{2}$ & $\begin{array}{c}-1.61 \\
(-2.34,-0.88)\end{array}$ & & $\begin{array}{c}0.55 \\
(-0.51,1.61)\end{array}$ & $\begin{array}{c}1.57 \\
(0.65,2.49)\end{array}$ & & & \\
\hline$g_{3}$ & $\begin{array}{c}-1.75 \\
(-2.83,-0.67)\end{array}$ & $\begin{array}{c}0.01 \\
(-0.024,0.044)\end{array}$ & $\begin{array}{c}0.56 \\
(-0.50,1.62)\end{array}$ & $\begin{array}{c}1.57 \\
(0.65,2.49)\end{array}$ & & & \\
\hline$g_{4}$ & $\begin{array}{c}-1.91 \\
(-4.2,-0.65)\end{array}$ & $\begin{array}{c}0.01 \\
(-0.10,0.12)\end{array}$ & $\begin{array}{c}0.55 \\
(-0.52,1.62)\end{array}$ & $\begin{array}{c}1.57 \\
(0.65,2.49)\end{array}$ & $\begin{array}{c}0.01 \\
(-0.11,0.13)\end{array}$ & & \\
\hline$g_{5}$ & $\begin{array}{c}-2.45 \\
(-4.22,-0.68)\end{array}$ & $\begin{array}{c}0.04 \\
(-0.02,0.10)\end{array}$ & $\begin{array}{c}2.17 \\
(-0.35,4.69)\end{array}$ & $\begin{array}{c}2.26 \\
(1.17,3.35)\end{array}$ & & $\begin{array}{c}-0.07 \\
(-0.12,-0.02)\end{array}$ & $\begin{array}{c}-0.03 \\
(-0.07,0.01)\end{array}$ \\
\hline
\end{tabular}


crab size in Gracilaria vermiculophylla, indicating that $G$. vermiculophylla served as an effective nursery habitat for a wider range of juvenile crab sizes.

\section{DISCUSSION}

Due to an extensive eelgrass decline and the spread of the exotic macroalga Gracilaria vermiculophylla in Chesapeake Bay, we suspected that $G$. vermiculophylla could be forming a novel ecosystem (sensu Hobbs et al. 2006, 2009) by providing structured nursery habitat for the blue crab and many other species reliant on seagrass for refuge (Beck et al. 2001, Lipcius et al. 2007). Our field surveys and experiments confirmed that $G$. vermiculophylla is utilized by blue crab juveniles, and that juveniles survive in G. vermiculophylla patches as well as or better than in eelgrass Zostera marina patches or unvegetated mud habitat. In addition, there appears to be a positive relationship between density of juvenile crabs and volume of $G$. vermiculophylla. Consequently, recovery of the blue crab from a major decline (Lipcius \& Stockhausen 2002) may be facilitated by an exotic macroalgal species. Furthermore, we validated the role of predation-induced changes in survival in mediating an ontogenetic shift of juveniles from seagrass to unvegetated mud habitats as they grow, and that G. vermiculophylla supersedes the need for an ontogenetic habitat shift by providing suitable refuge for a wider size range of juvenile blue crabs than either eelgrass or unvegetated mud habitats.

We posit that the Chesapeake Bay ecosystem is transitioning into a functionally novel ecosystem due in part to the emergence of an exotic, habitat-forming species that is replacing the disappearing native eelgrass as nursery habitat. This situation can be conceptualized for an array of ecosystems and their restoration potential under various environmental and biotic conditions, such as the loss of native species or addition of exotic species (Fig. 3), as originally suggested by Hobbs et al. (2009). The Chesapeake Bay ecosystem similarly experienced an alteration from a 'historical' ecosystem state within its natural range of variability (lower left quadrant, Fig. 3) to a degraded 'altered' state (lower right quadrant), in which a substantial fraction of the bay's eelgrass beds have been destroyed (Orth \& Moore 1984, Orth et al. 2010). We postulate that the system is moving from the lower right quadrant towards the intersection of the upper left and right quadrants, such that the functional role of nursery habitats will, in the future, be filled by a mix of seagrass and Gracilaria ver-

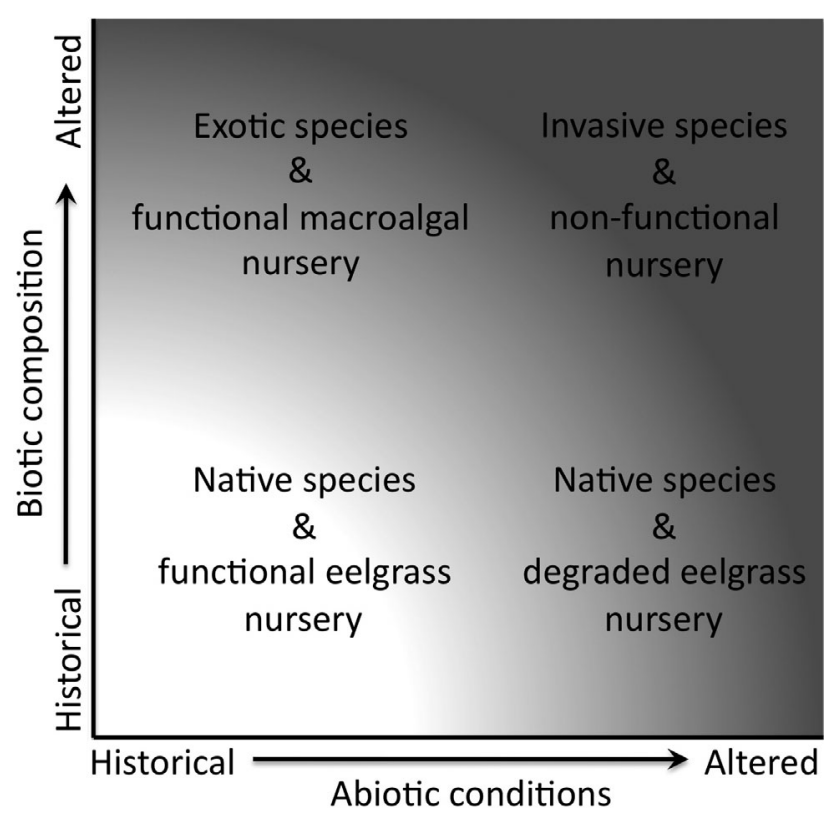

Fig. 3. Ecosystem types and their restoration potential under various conditions of biotic composition (loss of native species or addition of exotic species) and the abiotic environment (e.g. eutrophication), as adapted from Hobbs et al. (2009; their Fig. 1d). Each axis grades from a 'historical' ecosystem state within its natural range of variability to an 'altered' or 'novel' state where the ecosystems have experienced substantial modifications in abiotic conditions or biotic composition. In the case of Chesapeake Bay, the system initially shifted from the lower left (native species, suitable environment, functional eelgrass Zostera marina nursery habitat) to the lower right (eutrophication, degraded eelgrass nursery habitat). We postulate that the system is shifting towards the intersection of the upper left and right quadrants, with a mix of seagrass and Gracilaria vermiculophylla nursery habitats for the blue crab and other species. Note that the upper left quadrant lists beneficial 'exotic' species in a functional ecosystem, whereas it is assumed that a degraded ecosystem will contain deleterious 'invasive' species (upper right quadrant)

miculophylla nursery habitats for the blue crab and other species under a different set of environmental conditions than those that historically occurred in Chesapeake Bay. Through the establishment and spread of an exotic species, the ecosystem is therefore becoming more efficient at supporting a diverse suite of marine and estuarine species than in the absence of eelgrass habitat (e.g. Thomsen et al. 2010, Byers et al. 2012).

\section{Ontogenetic tradeoffs in nursery habitats}

Our field experiments demonstrated that juvenile survival was positively related to crab size in mud but negatively in seagrass, which corroborated the para- 
digm of a predation-induced ontogenetic shift from seagrass to unvegetated habitat. The interaction effect between crab size and habitat type most likely relates to disparate preferences for structured and unstructured habitats by different juvenile size classes (Orth \& van Montfrans 1987, 2002, Pile et al. 1996, Hovel \& Lipcius 2001, Lipcius et al. 2007). Young, small juvenile blue crabs may require the structural refuge of vegetation, whereas larger juveniles that have reached a size refuge in unvegetated mud habitats can escape cannibalism in structured nurseries and safely exploit productive foraging grounds in unvegetated mud habitat (Seitz et al. 2005). Equally, the interaction may originate from effective scaling of structural refuge to prey body size such that different types of structural refuge are effective for different juvenile size ranges. For example, although large Nassau grouper juveniles remain at the periphery of macroalgae, they outgrow the finer refuge of algal interstices and shift to larger crevices provided by patch corals (Dahlgren \& Eggleston 2000). Predator suites may also vary by habitat and prey size, which could produce an interaction effect, especially if the predators within each habitat vary in prey size limitation (Orth \& van Montfrans 1987).

The graphical intersection in survival probability from the size $\times$ habitat model $\left(g_{5}\right)$ indicates that a sizespecific habitat shift of blue crab juveniles should occur at about 20 to $30 \mathrm{~mm} \mathrm{CW}$ from seagrass to mud, which was corroborated by natural juvenile densities and size distributions. In various field studies, juvenile survival in mud and seagrass habitats converged when crabs reached 20 to $30 \mathrm{~mm}$ CW (Pile et al. 1996, Hovel \& Lipcius 2001, Lipcius et al. 2005, 2007). Similar patterns have been observed for other marine species (finfish and crustaceans: Ruiz et al. 1993; ribbed mussel: Lee \& Kneib 1994; Nassau grouper: Dahlgren \& Eggleston 2000). In contrast to the pattern for survival, growth of juvenile blue crabs was comparable between seagrass and mud habitats (Seitz et al. 2005), suggesting that growth has a minimal influence on habitat preference. Thus, blue crab ontogenetic habitat preference supports the 'minimize mortality risk $(\mu)^{\prime}$ hypothesis (Werner \& Hall 1988).

\section{Suitability of Gracilaria vermiculophylla as nursery habitat}

In the field experiments, Gracilaria vermiculophylla generated the highest probability of survival for all juvenile sizes of the 3 habitats tested. In the field sampling of G. vermiculophylla patches, crab densities were high, crab size structure was typical of that occurring in native seagrass habitat, and crab density appeared to be positively correlated with $G$. vermiculophylla volume, indicating that it is effective as both primary (early juvenile) and secondary (late juvenile) nursery habitat. Most importantly, the comparatively high survival of juveniles in $G$. vermiculophylla indicates that this vegetation can serve as an alternative to the structural refuge provided by previously abundant eelgrass Zostera marina beds. This is in keeping with the hypothesis that shelter-seeking species use structural complexity rather than evolutionary familiarity to determine their use of habitat-forming vegetation (Duffy \& Baltz 1998, Jackson \& Hobbs 2009, Martin \& Valentine 2011, Schlaepfer et al. 2011). In addition, prey items occurring in macroalgae such as G. vermiculophylla provide the necessary food quality to support juvenile crab growth (Epifanio et al. 2003, Thomsen et al. 2009, Byers et al. 2012).

The mechanism by which Gracilaria vermiculophylla produces higher survival in a wider range of juvenile sizes than seagrass remains unexplored. If the branching structure of G. vermiculophylla provides more rugosity than seagrass blades, then the inverse relationship between habitat complexity and predation pressure may explain the wider array of juvenile sizes surviving in its refuge (Coull \& Wells 1983, Tupper \& Boutilier 1997, Martin \& Valentine 2011). Similarly, the branching structure of G. vermiculophylla may functionally scale to a broader array of body sizes, as documented in Nassau grouper, whose small juveniles inhabited macroalgal branch interstices, whereas large juveniles resided along algal clump edges (Dahlgren \& Eggleston 2000).

Although Gracilaria vermiculophylla provides refuge for juvenile blue crab and other estuarine species, its benefits will likely vary temporally due to seasonal patterns in abundance, disturbances such as storms, and hydrodynamic conditions (Thomsen et al. 2010). In addition, it may be harmful to the ecosystem in places where it forms dense beds that foster hypoxia (Gray et al. 2002, Bell \& Eggleston 2005). In the mainstem tributaries of Chesapeake Bay, we have observed only a few places where G. vermiculophylla formed dense beds, typically in small coves lacking sufficient water flow. This is in contrast to the coastal bays and seaside lagoons adjoining the Chesapeake, where dense beds are common (Thomsen et al. 2010). Hence, the effects of G. vermiculophylla in the ecosystem may generally be positive, though additional field surveys on its wide-scale effects in Chesapeake Bay are necessary, as done previously in the coastal bays and lagoons (Thomsen et al. 2010). 


\section{Implications for conservation}

The positive effects of the exotic Gracilaria vermiculophylla in fostering survival of the native blue crab, in addition to the poor prognosis for recovery of eelgrass in Chesapeake Bay, indicate that a novel ecosystem is emerging with $G$. vermiculophylla as a critical habitat-forming species. Native, shelterseeking species are apparently more influenced by refuge structural complexity than vegetation origin (i.e. native versus exotic), as observed in other terrestrial and aquatic ecosystems (Schlaepfer et al. 2011). Consequently, the exotic G. vermiculophylla should be included in conservation assessments of structured benthic habitat availability, especially in areas already impacted by native habitat degradation. In today's rapidly changing ecosystems, the future of effective conservation may lay in the reassessment of novel ecological relationships (Hobbs et al. 2006, 2009), especially our understanding of native-exotic interactions. While preservation of historical native ecosystems remains the primary goal, recognition and assessment of novel ecosystems may provide powerful new conservation approaches (Jackson \& Hobbs 2009, Schlaepfer et al. 2011).

Acknowledgements. We thank the Virginia Institute of Marine Science (VIMS) Marine Conservation Biology and Community Ecology Labs and VIMS 2007 National Science Foundation-Research Experiences for Undergraduates (REU) interns for field assistance. This project was made possible through a grant to R.N.L. from Virginia Sea Grant, National Science Foundation REU grants to L. Schaffner and R. Seitz, a National Oceanic and Atmospheric Administration grant to R. Seitz and R.N.L. through the Blue Crab Advanced Research Consortium, and a Hampshire College Coppinger Research Grant to C.A.J. This is contribution no. 3240 from the Virginia Institute of Marine Science.

\section{LITERATURE CITED}

Anderson DR (2007) Model-based inference in the life sciences: a primer on evidence. Springer, New York, NY

- Beck MW, Heck KL Jr, Able KW, Childers DL and others (2001) The identification, conservation, and management of estuarine and marine nurseries for fish and invertebrates. Bioscience 51:633-641

Bell GW, Eggleston DB (2005) Species-specific avoidance responses by blue crabs and fish to chronic and episodic hypoxia. Mar Biol 146:761-770

Bellorin AM, Oliveira MC, Oliveira EC (2004) Gracilaria vermiculophylla: a western Pacific species of Gracilariaceae (Rhodophyta) first recorded from the eastern Pacific. Phycol Res 52:69-79

Burnham KP, Anderson DR (2002) Model selection and multimodel inference: a practical information-theoretic approach, 2nd edn. Springer, New York, NY

Byers JE, Gribben PE, Yeager C, Sotka EE (2012) Impacts of an abundant introduced ecosystem engineer within mudflats of the southeastern US coast. Biol Invasions (in press) doi:10.1007/s10530-012-0254-5

> Coull BC, Wells JBJ (1983) Refuges from fish predation: experiments with phytal meiofauna from the New Zealand rocky intertidal. Ecology 64:1599-1609

Craig JK, Crowder LB (2000) Factors influencing habitat selection in fishes with a review of marsh ecosystems. In: Weinstein MP, Kreeger DA (eds) Concepts and controversies in tidal marsh ecology. Kluwer Academic Publishers, Norwell, MA, p 241-266

Dahlgren CP, Eggleston DB (2000) Ecological processes underlying ontogenetic habitat shifts in a coral reef fish. Ecology 81:2227-2240

Duarte CM (1995) Submerged aquatic vegetation in relation to different nutrient regimes. Ophelia 41:87-112

> Duffy KC, Baltz DM (1998) Comparison of fish assemblages associated with native and exotic submerged macrophytes in the Lake Pontchartrain estuary, USA. J Exp Mar Biol Ecol 223:199-221

Epifanio CE, Dittel AI, Rodriguez RA, Targett TE (2003) Macroalgal beds as nursery habitat for juvenile blue crabs, Callinectes sapidus. J Shellfish Res 22:881-886

Freshwater DW, Montgomery F, Greene JK, Hamner RM, Williams M, Whitfield PE (2006) Distribution and identification of an invasive Gracilaria species that is hampering commercial fishing operations in southeastern North Carolina, USA. Biol Invasions 8:631-637

Goodenough AE (2010) Are the ecological impacts of alien species misrepresented? A review of the 'native good, alien bad' philosophy. Commun Ecol 11:13-21

> Gray JS, Rudolf SW, Or YY (2002) Effects of hypoxia and organic enrichment on the coastal marine environment. Mar Ecol Prog Ser 238:249-279

> Halpin PM (2000) Habitat use by an intertidal salt-marsh fish: trade-offs between predation and growth. Mar Ecol Prog Ser 198:203-214

Heck KL Jr, Spitzer PM (2001) Post settlement mortality of juvenile blue crabs: patterns and processes. In: Guillory V, Perry H, Vanderkooy S (eds) Proceedings of the Blue Crab Mortality Symposium. Gulf States Marine Fisheries Commission Publication 90. Ocean Springs, MS, p 18-27

Hines AH, Ruiz GM (1995) Temporal variation in juvenile blue crab mortality: nearshore shallows and cannibalism in Chesapeake Bay. Bull Mar Sci 57:884-901

- Hobbs RJ, Arico S, Aronson J, Baron JS and others (2006) Novel ecosystems: theoretical and management aspects of the new ecological world order. Glob Ecol Biogeogr 15:1-7

> Hobbs RJ, Higgs E, Harris JA (2009) Novel ecosystems: implications for conservation and restoration. Trends Ecol Evol 24:599-605

> Hovel KA, Lipcius RN (2001) Habitat fragmentation in a seagrass landscape: Patch size and complexity control blue crab survival. Ecology 82:1814-1829

> Jackson ST, Hobbs RJ (2009) Ecological restoration in the light of ecological history. Science 325:567-569

$>$ Lee SY, Kneib RT (1994) Effects of biogenic structure on prey consumption by the xanthid crabs Eurytium limosum and Panopeus herbstii in a salt marsh. Mar Ecol Prog Ser 104:39-47

Lipcius RN, Stockhausen WT (2002) Concurrent decline of the spawning stock, recruitment, larval abundance, and size of the blue crab Callinectes sapidus in Chesapeake Bay. Mar Ecol Prog Ser 226:45-61 
Lipcius RN, Seitz RD, Seebo MS, Colon-Carrion D (2005) Density, abundance, and survival of the blue crab in seagrass and unstructured salt marsh nurseries of Chesapeake Bay. J Exp Mar Biol Ecol 319:69-80

Lipcius RN, Eggleston DB, Heck KL Jr, Seitz RD, van Montfrans J (2007). Ecology of postlarval and young juvenile blue crabs. In: Kennedy VS, Cronin LE (eds) The blue crab, Callinectes sapidus. University of Maryland Sea Grant Press, College Park, MD, p 535-564

> Martin CW, Valentine JF (2011) Impacts of a habitat-forming exotic species on estuarine structure and function: an experimental assessment of Eurasian milfoil. Estuaries Coasts 34:364-372

McPeek MA, Grace M, Richardson JML (2001) Physiological and behavioral responses to predators shape the growth/predation risk trade-off in damselflies. Ecology 82:1535-1545

Mooney HA, Cleland EE (2001) The evolutionary impacts of invasive species. Proc Natl Acad Sci USA 98:5446-5451

Ohmi H (1956) Contributions to the knowledge of Gracilariaceae from Japan. II. On a new species of the genus Gracilariopsis, with some considerations on its ecology. Bull Fac Fish Hokkaido Univ 6:271-279

Orth RJ, Moore KA (1984) Distribution and abundance of submerged aquatic vegetation in Chesapeake Bay: an historical perspective. Estuaries Coasts 7:531-540

> Orth RJ, van Montfrans J (1987) Utilization of a seagrass meadow and tidal marsh creek by blue crabs Callinectes sapidus. I. Seasonal and annual variations in abundance with emphasis on post-settlement juveniles. Mar Ecol Prog Ser 41:283-294

Orth RJ, van Montfrans J (2002) Habitat quality and prey size as determinants of survival in post-larval and early juvenile instars of the blue crab Callinectes sapidus. Mar Ecol Prog Ser 231:205-213

Orth RJ, Wilcox DJ, Whiting JR, Nagey LS, Owens LA, Kenne AK (2008). Distribution of submerged aquatic vegetation in the Chesapeake Bay and coastal bays 2007. VIMS Special Scientific Report Number 151. Final report to US EPA Chesapeake Bay Program, Annapolis, MD, available at www.vims.edu/bio/sav/sav07

Orth RJ, Marion SR, Moore KA, Wilcox DJ (2010) Eelgrass (Zostera marina L.) in the Chesapeake Bay region of Mid-Atlantic coast of the USA: challenges in conservation and restoration. Estuaries Coasts 33:139-150

> Pardieck RA, Orth RJ, Diaz RJ, Lipcius RN (1999) Ontogenetic changes in habitat use by postlarvae and young juveniles of the blue crab. Mar Ecol Prog Ser 186:227-238

Penhale PA, Thayer GW (1980) Uptake and transfer of carbon and phosphorus by eelgrass (Zostera marina L.) and its epiphytes. J Exp Mar Biol Ecol 42:113-123

Peterson CH, Black R (1994) An experimentalist's challenge: when artifacts of intervention interact with treatments. Mar Ecol Prog Ser 111:289-297

Pile AJ, Lipcius RN, van Montfrans J, Orth RJ (1996) Den-

Editorial responsibility: Richard Osman,

Edgewater, Maryland, USA sity-dependent settler-recruit-juvenile relationships in blue crabs. Ecol Monogr 66:277-300

Rodriguez LF (2006) Can invasive species facilitate native species? Evidence of how, when, and why these impacts occur. Biol Invasions 8:927-939

Ruiz GM, Hines AH, Posey MH (1993) Shallow water as a refuge habitat for fish and crustaceans in non-vegetated estuaries: an example from Chesapeake Bay. Mar Ecol Prog Ser 99:1-16

Sand-Jensen K, Borum J (1991) Interactions among phytoplankton, periphyton, and macrophytes in temperate freshwaters and estuaries. Aquat Bot 41:137-175

Schlaepfer MA, Sax DF, Olden JD (2011) The potential conservation value of non-native species. Conserv Biol 25: 428-437

Seitz RD, Lipcius RN, Seebo MS (2005) Food availability and growth of the blue crab in seagrass and unvegetated nurseries of Chesapeake Bay. J Exp Mar Biol Ecol 319: 57-68

> Thomsen MS (2010) Experimental evidence for positive effects of invasive seaweed on native invertebrates via habitat-formation in a seagrass bed. Aquat Invasions 5: 341-346

Thomsen MS, Gurgel CFD, Fredericq S, McGlathery KJ (2006a) Gracilaria vermiculophylla (Rhodophyta, Gracilariales) in Hog Island Bay, Virginia: a cryptic alien, invasive macroalgae and taxonomic correction. J Phycol 42: 139-141

Thomsen MS, McGlathery KJ, Tyler C (2006b) Macroalgal distribution patterns in a shallow, softbottom lagoon, with emphasis on the nonnative Gracilaria vermiculophylla and Codium fragile. Estuaries Coasts 29:465-473

Thomsen MS, Staehr PA, Nyberg CD, Schwaerter S, KrauseJenson D, Silliman BR (2007) Gracilaria vermiculophylla (Ohmi) Papenfuss, 1967 (Rhodophyta, Gracilariaceae) in northern Europe, with emphasis on Danish conditions, and what to expect in the future. Aquat Invasions 2: 83-96

Thomsen MS, McGlathery KJ, Schwarzschild A, Silliman BR (2009) Distribution and ecological role of the non-native macroalga Gracilaria vermiculophylla in Virginia salt marshes. Biol Invasions 11:2303-2316

Thomsen MS, Wernberg T, Altieri A, Tuya F and others (2010) Habitat cascades: the conceptual context and global relevance of facilitation cascades via habitat formation and modification. Integr Comp Biol 50:158-175

Tupper M, Boutilier RG (1997) Effects of habitat on settlement, growth, predation risk and survival of a temperate reef fish. Mar Ecol Prog Ser 151:225-236

> Werner EE, Gilliam JF (1984) The ontogenetic niche and species interactions in size-structured populations. Annu Rev Ecol Syst 15:393-425

> Werner EE, Hall DJ (1988) Ontogenetic habitat shifts in bluegill: the foraging rate-predation risk trade-off. Ecology 69:1352-1366

Submitted: March 18, 2011; Accepted: July 10, 2012 Proofs received from author(s): October 17, 2012 